\title{
Pelatihan Kewirausahaan Bagi Remaja Karang Taruna Di Desa Dayeuh
}

\author{
Ermi Herawati ${ }^{1}$, Putri Puspitasari ${ }^{2}$, Maya Susanti ${ }^{3}$, Nanih Rahmahdani ${ }^{4}$ \\ 1,2,3,4Program Studi Manajemen Bisnis Syariah, STEBIS Bina Mandiri Cileungsi, Bogor \\ email: ermi@binamandiri.ac.id, putrips@gmail.com, mayass@gmail.com, nanihrh@gmail.com
}

\begin{abstract}
Abstrak: Tujuan dari pengabdian ini adalah memberikan bekal bagi remaja karang taruna di Desa Dayeuh agar memiliki keterampilan, pengetahuan dan sikap dalam memasuki dunia wirausaha yang mandiri sebagai salah satu upaya dalam rangka menumbuhkan kecakapan hidup bagi anakanak yang tinggal di panti asuhan dengan memberikan pendidikan non formal dalam bidang kewirausahaan. Pelatihan yang dilakukan tidak berupa pemberian materi tetapi melalui praktek langsung kepada anak-anak panti asuhan yang notabene adalah siswa siswi sekolah menengah pertama sampai dengan sekolah menengah tingkat atas. Praktek yang dilakukan berupa pembuatan makanan berbahan dasar pisang dengan kreasi dan inovasi yang berbeda. Target luaran dari program pengabdian ini adalah meningkatkan kepedulian dosen kepada masyarakat, selain itu dapat menjadi motivasi dan inspirasi bagi anak-anak panti asuhan saat nanti memulai berwirausaha. Dengan pengetahuan kewirausahaan yang mumpuni, diharapkan akan mampu menumbuhkan sikap kemandirian yang matang, agar biaya hidup dan biaya pendidikan dapat berjalan lancar serta dapat membantu meringankan beban panti, maka mereka perlu diberdayakan untuk perbaikan kualitas hidupnya.
\end{abstract}

Kata Kunci: Kewirausahaan, Kreativitas, Inovasi

Abstract: The purpose of this service is to provide provisions for youth youth organizations in Dayeuh Village to have the skills, knowledge and attitudes in entering the world of independent entrepreneurship as an effort to grow life skills for children living in orphanages by providing nonformal education. in the field of entrepreneurship. The training carried out was not in the form of providing material but through direct practice to orphanage children who incidentally were students from junior high school to senior high school. The practice is in the form of making banana-based foods with different creations and innovations. The output target of this service program is to increase the awareness of lecturers to the community, besides that it can be a motivation and inspiration for orphanage children when they start entrepreneurship. With good entrepreneurial knowledge, it is hoped that they will be able to grow a mature attitude of independence, so that the cost of living and education costs can run smoothly and can help ease the burden of the orphanage, so they need to be empowered to improve their quality of life.

Keywords: Entrepreneurship, Creativity, Innovation

\section{Pendahuluan}

Fenomena di Indonesia mayoritas lulusan SLTA $(61,88 \%)$ lebih memilih menjadi karyawan daripada menjadi wirausaha. Sejalan dengan hal tersebut, maka diperlukan adanya pelatihan kewirausahaan sejak dini kepada kelompok masyarakat. Target kegiatan pengabdian kepada masyarakat ini adalah menumbuhkan keterampilan wirausaha baru dari kalangan remaja karang taruna yang berlokasi di Desa Dayeuh. Pelatihan kewirausahaan bagi remaja ini ditujukan agar mereka bisa hidup mandiri di masyarakat. Namun demikian untuk mencapai kemandirian finansial bukan kondisi yang dapat diciptakan dalam waktu singkat. Kemandirian tersebut perlu ditumbuhkembangkan dari waktu ke waktu.

Perlunya menumbuhkan jiwa kewirausahaan dari sejak dini dikarenakan pada usia 
yang masih muda semangat yang dimiliki masih besar, daya kreasi dan inovasi sangat tinggi begitu juga dengan energi yang dimiliki. Guna mendukung hal tersebut, para wirausahawan muda ini harus dibekali dengan keterampilan-keterampilan guna mengembangkan dan membentuk karakteristik wirausahawan muda yang tangguh dan siap berkompetisi sekaligus bersaing dalam bisnis yang sama. Keterampilan usaha yang dimiliki oleh anak-anak panti asuhan juga masih tergolong sangat terbatas, karena belum pernah mendapatkan pendampingan dari pihak-pihak yang berkompeten dalam bidang kewirausahaan. Padahal jika dilihat dari usia mereka yang tergolong produktif, mereka memiliki potensi untuk berkembang dalam kegiatan kewirausahaan yang kreatif sesuai jiwa muda anak-anak panti asuhan. Kendala lain yang dihadapi Panti Asuhan pada umumnya adalah rendahnya motivasi wirausaha.

Dalam hal ini kami membidik remaja karang taruna yang berlokasi di Desa Dayeuh Kecamatan Cileungsi. Alasan kami memilih remaja karang taruna yang berlokasi di Desa Dayeuh ini dikarenakan remaja karang taruna yang berlokasi di Desa Dayeuh ini belum mendapatkan materi kewirausahaan yang akan membantu mereka menghadapi persaingan yang semakin ketat dalam bidang pekerjaan. Berdasarkan hasil wawancara yang dilakukan terhadap anak asuh panti, disimpulkan bahwa sebagian besar mereka memiliki kecerdasan yang sama dengan remaja-remaja lainnya yang memiliki hidup sangat layak, namun untuk kemandirian, kematangan emosi dan kematangan sosial dirasakan masih sangat kurang.

Hasil identifikasi menunjukkan ada permasalahan yang dihadapi dan harus dipecahkan oleh Tim pelaksana jika dilihat dari berbagai sudut pandang yang relevan, yaitu pertama adalah ketrampilan kewirausahaan yang dimiliki masih terbatas. Kedua, belum memiliki target dan sasaran usaha apa yang akan dibuat. Ketiga, belum memiliki keahlian dalam promosi dan pemasaran. Salah satu upaya kami dalam membantu menyelesaikan masalah-masalah yang dihadapi yaitu dengan cara menumbuhkan keterampilan wirausaha di kalangan remaja karang taruna yang berlokasi di Desa Dayeuh berupa pelatihan keterampilan pengolahan makanan berbahan dasar pisang, karena kami lihat usaha ini sedang memiliki prospek yang cukup baik, banyak konsumennya, cukup mudah pembuatannya, dan modal yang diperlukan tidak terlalu besar. Dengan mendapatkan pelatihan keterampilan tersebut diharapkan dapat menjadi sarana bagi penghuni panti untuk mengasah soft skill dan termotivasi untuk berwirausaha.

Pelatihan yang diajarkan tidak hanya sekedar untuk mengembangkan ketrampilan maupun mengasah soft skill saja, akan tetapi dapat digunakan untuk menambah uang saku, dan mereka akan menjadi lebih mandiri secara finansial. Berdasarkan uraian diatas, maka perlu dilakukan pelatihan tentang bagaimana menumbuhkan keterampilan wirausaha melalui pengolahan makanan berbahan dasar pisang terhadap remaja di panti asuhan al-fajar Pekanbaru.

Kegiatan ini memiliki tujuan untuk memberi pelatihan bagaimana menumbuhkan 
keterampilan wirausaha melalui pengolahan makanan berbahan dasar pisang terhadap remaja karang taruna yang berlokasi di Desa Dayeuh. Dari penyuluhan ini diharapkan dapat memberikan manfaat Bagi remaja karang taruna yang berlokasi di Desa Dayeuh memiliki bekal keterampilan wirausaha sehingga di masa depan mampu menjalani kehidupan secara mandiri serta menumbuhkan kreatifitas dan inovasi dalam hal berwirausaha.

\section{Metode}

Pengabdian ini dilaksanakan bagi remaja karang taruna yang berlokasi di Desa Dayeuh. Pelaksanaan pengabdian ini melibatkan beberapa pihak, diantaranya kepala desa beserta jajaran lainnya dan anak-anak remaja yang sekaligus merupakan peserta pelatihan. Metode kegiatan pengabdian masyarakat ini berupa pemberian pelatihan melalui praktek keterampilan, diskusi dan Tanya jawab.

Pelaksanaan pengabdian ini dilakukan dengan tiga tahap. Tahap awal pengabdian ini yaitu tahapan persiapan. Pada tahap ini tim pelaksana kegiatan melakukan konsultasi dengan anggota yang lain. Kemudian melakukan survey dan observasi terhadap para remaja dan melakukan koordinasi kepada pihak yang bersangkutan. Tahap kedua yaitu tahap pelaksanaan kegiatan pengabdian, Pada tahapan ini tim terlebih dahulu melakukan silaturrahmi sebelum pelatihan diselenggrakan, kemudian berbincang dengan para pengasuh seputar kondisi anak-anak panti khususnya yang berkaitan dengan pendidikan kewirausahaan. Setelah itu, tim langsung memberikan praktik keterampilan wirausaha. Setiap peserta pengabdian mendengarkan paparan dari narasumber sekaligus ikut terlibat langsung dalam proses pembuatan.

Selama proses pelatihan berlangsung, peserta diberi kesempatan untuk bertanya secara langsung bersamaan setelah itu tim juga memberikan pengalaman bagaimana memulai usaha dan mengasah kreativitas dan inovasi dalam mengelola usaha. Tahap terakhir yaitu tahap evaluasi. Rencana evaluasi pelaksanaan dengan mengadakan pengamatan langsung di lapangan terhadap peserta pelatihan. Evaluasi yang dilakukan dengan mengecek minat anak asuh dalam berwirausaha, mengecek kondisi usaha yaitu keadaan usaha, sudah berjalan atau belum berjalan, prestasi yang dicapai terkait dengan omset, kondisi keuangan, jangkauan pasar, dan jumlah variasi produk.

\section{Hasil dan Pembahasan}

Pengabdian kepada masyarakat yang dilaksanakan di Desa Dayeuh Kecamatan Cileungsi Kabupaten Bogor, Jawa barat. Kegiatan ini dilaksanakan sesuai dengan jadwal yang telah ditetapkan dan di sepakati bersama dengan pihak remaja karang taruna Desa Dayeuh. Langkah awal yang dilakukan yaitu persiapan dan permohonan izin kepada pihak 
Kepala Desa yang menjadi tujuan pengabdian masyarakat, selanjutnya dilakukan pencarian informasi jumlah peserta dan kegiatan. peserta sebelum di adakan pelatihan.

Setelah waktu pelaksanaan di sepakati, tim dari dosen Prodi Manajemen Bisnis Syariah STEBIS Bina Mandiri menyusun jadwal pelaksanaan dan membuat kesepakatan dengan pihak Kepala Desa mengenai jadwal pelaksanaan. Kegiatan pelatihan ini dilaksanakan dalam rangka melaksanakan Tri Dharma Perguruan Tinggi, yang salah satunya adalah pengabdian kepada masyarakat. Pelatihan ini diberikan untuk remaja karang taruna, adapun bentuk pelatihan yang dilakukan adalah keterampilan wirausaha remaja melalui pelatihan pengolahan makanan berbahan dasar pisang. Pelatihan ini diberikan untuk menambah keterampilan dan pengetahuan bagi remaja karang taruna di Desa Dayeuh karena keterampilan yang dimiliki remaja karang taruna di Desa Dayeuh juga masih sangat terbatas.

Dalam proses pelaksanaan pelatihan tahapan pertama yang dilakukan dimulai dengan tahapan persiapan, di mana tim pelaksana melakukan briefing untuk penyiapan bahan-bahan yang dibutuhkan pada saat pelatihan, membagi tugas masing-masing pembicara, menyiapkan para peserta pelatihan, menyiapkan materi pelatihan yang berhubungan dengan pembimbingan dan praktik berwirausaha. Kegiatan dilaksanakan sesuai dengan waktu yang telah di sepakati bertempat di Balai Desa Dayeuh. Tahapan pelaksaaan kegiatan dimulai dengan bersilaturrahmi dan pelatihan keterampilan pengolahan makanan berbahan dasar pisang. Tahapan pelaksanan selanjutnya yaitu diskusi dan sharing experience bersama anakanak panti asuhan. Pelatihan diberikan kepada seluruh peserta berupa cara membuat produk makanan yang menarik dan memiliki daya jual di pasaran. Saat pelatihan berlangsung tim juga menyelipkan sedikit penjelasan bagaimana membuat produk yang kreatif dan inovatif serta alasan kenapa produk ini yang dipilih dalam praktik pelatihan. Peserta juga di berikan kesempatan untuk bertanya seputar produk maupun yang berkaitan dengan pemasaran produk.

Evaluasi pada tahap pertama telah sesuai dengan indikator dan rancangan evaluasi diperoleh data sebagai berikut:

1. Jumlah peserta yang hadir sebanyak 22 remaja sehingga tingkat kehadiran mencapai $100 \%$.

2. Peserta sangat terlihat antusias selama mengikuti kegiatan hingga pelatihan selesai

3. Setiap peserta aktif mengutarakan pertanyaan dan diskusi dalam pemecahan masalah dan kendala yang dialami pada saat memulai dan menjalankan usaha.

4. Setelah dilakukan pelatihan diharapkan para remaja karang taruna di Desa Dayeuh memiliki karakteristik wirausahawan muda yang tangguh dan siap berkompetisi sekaligus bersaing dalam bisnis yang sama. Secara umum evaluasi yang dilakukan terlaksana dengan baik, dan peserta dan pengasuh panti asuhan berharap kegiatan ini terus berkelanjutan kedepannya dengan variasi produk yang berbeda dan lebih inovatif 


\section{Kesimpulan}

Pelatihan yang dilakukan pada akhirnya mampu menumbuhkan intensi mereka untuk berwirausaha karena proses kegiatan pembuatan makanan berbahan dasar pisang ini mudah diingat dan mudah dilakukan sehingga setelah kegiatan pelatihan ini berakhir peserta mampu membuat produk itu sendiri dan bersedia menjual produk itu sebagai usaha dalam menumbuhkan jiwa wirausaha.

Peserta merespon kegiatan pelatihan ini dengan baik. Mereka merasa senang dan nyaman selama mengikuti kegiatan pelatihan. Mereka juga mampu mengikuti setiap arahan dari pemateri dan sangat antusias mengikuti kegiatan pelatihan ini mulai dari awal hingga akhir pelatihan, hal ini dikarenakan sangat jarang mereka mendapatkan kegiatan dalam bentuk praktek yang dapat menambah ketrampilan dan melatih kemandirian melalui pelatihan.

\section{Referensi}

Alma, B. (2007). Kewirausahaan. Alpabeta.

Faraz, J. N. (2013). Makalah Kewirausahaan. Fakultas Ekonomi Universitas Negeri Yogyakarta.

Gitosudarmo, I. (2000). Manajemen Pemasaran. BPFE Siagian.

Hadibroto, C., Kartohadiprojo, N., \& Tobing, H. A. . (2007). Camilan Khas Indonesia. PT. Gramedia Pustaka Utama.

Kotler, P., \& Armstrong, G. (2008). Prinsip-Prinsip Pemasaran. (12th ed.). Erlangga.

Suryana. (2006). Kewirausahaan Pedoman Praktis: Kiat dan Proses Menuju Sukses. (Ketiga). Salemba.

Zimmerer, T. W., \& Scarborough, N. M. (2008). Kewirausahaan dan Manajemen Usaha Kecil. Salemba Empat. 